\title{
Should Transportation Spending be included in a Stimulus Program? A Review of the Literature
}

\author{
Sylvain Leduc \\ Federal Reserve Bank of San Francisco \\ Daniel J. Wilson \\ Federal Reserve Bank of San Francisco
}

September 2012

Working Paper 2012-15

http://www.frbsf.org/publications/economics/papers/2012/wp12-15bk.pdf

The views in this paper are solely the responsibility of the authors and should not be interpreted as reflecting the views of the Federal Reserve Bank of San Francisco or the Board of Governors of the Federal Reserve System. 


\title{
Should Transportation Spending be included in a Stimulus Program? A Review of the Literature
}

\author{
by \\ Sylvain Leduc \\ and \\ Daniel Wilson \\ (Federal Reserve Bank of San Francisco)
}

September 2012

Transportation spending often plays a prominent role in government efforts to stimulate the economy during downturns. Yet, despite the frequent use of transportation spending as a form of fiscal stimulus, there is little known about its short- or medium-run effectiveness. Does it translate quickly into higher employment and economic activity or does it impact the economy only slowly over time? This paper reviews the empirical findings in the literature for the United States and other developed economies and compares the effects of transportation spending to those of other types of government spending.

JEL Codes: E3, H3, H7, H4

Keywords: Infrastructure, Highways, Fiscal Policy, Economic Activity

Report Prepared for the National Academy of Sciences' Transportation Research Board, Committee on "Transportation Investments in Response to Economic Downturns" 


\section{Introduction}

Transportation spending often plays a prominent role in government efforts to stimulate the economy during downturns. In the United States during the Great Depression, programs such as the Works Progress Administration and the Tennessee Valley Authority were key elements of the government's economic stimulus. Most recently, to mitigate the effects of the downturn in the midst of the financial crisis, Congress passed the American Recovery and Reinvestment Act (ARRA) in the spring of 2009, the largest peacetime fiscal stimulus package in U.S. history. Of the estimated $\$ 825$ billion over ten years (according to CBO (2012)), about two-thirds comes from increased federal government spending, with the Department of Transportation receiving \$48 billion. Similarly, in the wake of the stock market collapse in Japan in 1989, the Japanese government initiated a series of stimulus packages with a significant emphasis on spending for public works, among which spending on roads figured prominently.

Yet, despite the frequent use of transportation spending as a form of fiscal stimulus, there is little known about its short- or medium-run effectiveness. Does it translate quickly into higher employment and economic activity or does it impact the economy only slowly over time? Or neither? This paper reviews the empirical findings in the literature for the United States and other developed economies and compares the effects of transportation spending to those of other types of government spending.

In principle, transportation spending could offer a potent way to stimulate economic activity when the economy is weak and simultaneously plant the seed for higher long-term economic growth. For many economists and policymakers the key issue is whether this form of spending can be implemented in a timely manner (one of Larry Summers (2008)'s conditions for an effective fiscal stimulus). New highway construction, for instance, typically has long implementation delays associated with the planning, design, and environmental review process that can take many years to complete even before actual construction begins. According to a 2002 GAO study, for a “federally financed major new construction highway project,” the typical timespan from initial planning to the completion of construction is between 9 and 19 years, with actual construction accounting for between 2 and 6 of those years (see GAO, 2002). Spending on such projects could thus be ineffective at mitigating the effects of recessions and instead could end up stimulating the economy when the expansion is already underway. As such, maintenance 
or repair projects or projects that are already under way and can be accelerated - often referred to as "shovel-ready" projects - stand a better chance to provide a more immediate economic boost.

Overall, the economics literature provides an unfortunately wide range of estimates regarding the effects of government investment in general, with relatively few studies concentrating on the effect of transportation spending and even fewer focusing on the specific issue of "stimulus" spending. ${ }^{1}$ Over the three studies we discuss below which report long run GDP multipliers of government investment, the range of estimates is between 0 and $4.5 .^{2}$ Of these, one study also reports a short run multiplier estimated to be roughly 1.7. Regarding the effects of transportation spending, Table 1 provides a brief overview of the key studies along with the multipliers they found. The two most relevant papers for this report are Leduc and Wilson (2012) and Pereira (2000). Leduc and Wilson find that changes in expectations of states future highway grants have large immediate, or "impact," effects on state GDP, with an impact multiplier as high as 2.7 and even larger long run effects. Looking at spending on highways and streets, Pereira (2000) estimates a long run national GDP multiplier of about 2.

The wide range of estimates shown in Table 1 is likely due to three major issues that make any empirical analysis of the effects of infrastructure spending on economic activity very challenging. The first difficulty is to identify clear and convincing causal effects. Because infrastructure spending is often used to stimulate the economy in downturns, reverse causation becomes a clear and likely concern, which could negatively bias the estimated effect of public spending. The literature has attempted to address this central issue from different angles, some more convincing than others, and this report will weigh in on the relative merits of the different approaches. Following the seminal work by Blanchard and Perotti (2002), most analyses adopt a timing assumption in which policymakers are assumed to be unable to react to current economic developments in the current period. Under this assumption, it is then possible to trace out the impact of fiscal policy on the economy without confounding the effects with the impact of

\footnotetext{
${ }^{1}$ We define "stimulus" spending as government spending during downturns intended as a countercyclical fiscal policy tool.

2 The "multiplier" on government spending is the dollar change in economic activity caused by a $\$ 1$ change in spending. For example, a GDP fiscal spending multiplier of 1.5 means that a $\$ 1$ increase in government spending leads to a $\$ 1.50$ increase in GDP. The multiplier is meant to capture the effects of fiscal policy on overall economic activity, not just the effects on those households or businesses directly receiving the spending. See Wilson (2012a) for a general discussion of the concept and empirical literature on the GDP multiplier of government spending.
} 
economic activity on fiscal policy. Clearly this timing assumptions is more realistic the shorter the time interval over which policymakers' hands are assumed to be tied. Hence, for the Blanchard and Perotti approach to work, it ideally should be implemented using data of relatively high frequency, which is not always the case in the literature. Alternatively, some researchers adopt strategies that, for instance, rely on knowledge of the institutional details for distributing federal transportation grants to states, which arguably is exogenous to current economic activity, or from quasi experiments.

The second issue is the accurate timing of government policy changes when there are implementation lags between policy legislation and the resulting changes in government outlays. Table 2, reproduced from Leduc and Wilson (2012), shows how severe these lags can be for spending on infrastructure. The table shows the coefficients from regressing the change in a state's obligations $\left(2^{\text {nd }}\right.$ column) or outlays $\left(3^{\text {rd }}\right.$ column$)$ on federal highway aid projects on lags of the change in federal highway grants. Roughly all of the grants are obligated, meaning funding projects have been chosen and initiated, within the first two years, but it takes nearly seven years for all of the funds to be outlaid; only $12 \%$ of grants are outlaid in the first year. These results imply that using data on outlays to identify the timing of a change in highway funding could give a misleading impression of when the actual policy change - which is when state government, contractors, and other economic agents may begin making decisions that affect the economy.

The third, and related, concern that arises with transportation or infrastructure spending is that it can likely be anticipated, sometimes many years in advance, which greatly complicates the identification of purely exogenous movements in government spending. Because infrastructure projects typically take many years to complete, the U.S. federal government, for instance, designs highway legislation so that states' transportation departments can have a fairly good idea of the amount of money they are likely to receive from the federal government in years to come, thus facilitating project planning. As convincingly emphasized by Ramey (2011), missing the timing of the 'news' about government spending - that is, failing to distinguish between when government spending changes - even if measured with grants instead of outlays - actually occur and when they were first anticipated - can lead to misleading inference about the effects of government spending. For example, if Congress suddenly and unexpectedly authorized a major 
increase in transportation spending but the authorization does not trigger an actual increase in government outlays for several years, much of any near-term impact of this spending may well occur at the time of the authorization - as businesses, local governments, and households anticipate the forthcoming construction activity and possible productivity gains - rather than at the time of the outlays. Unfortunately, most papers in the literature on infrastructure spending are subject to this criticism.

The empirical estimates in the literature naturally depend on the time period studied, particularly since the behavior of monetary policy and tax policy during a given period will affect the impact of infrastructure spending on economic activity. The role of monetary policy has been highlighted in recent theoretical work that emphasizes the importance of the zero lower bound on nominal interest rates (see, for instance, Christiano, Eichenbaum, and Rebelo (2010)). When nominal interest rates are at or close to zero percent, the effects of increases in government spending can be magnified compared to normal times when interest rates are positive. In normal times, any rise in actual or expected inflation resulting from increased government spending will cause the central bank to increase real interest rates which will act as a brake on economic activity. However, in times where short-term nominal interest rates are at the zero lower bound, any increase in inflation will cause lower real interest rates, which will act as an accelerator of economic activity. Thus, theory suggests that the effect of infrastructure spending on GDP would likely be larger when monetary policy is at the zero lower bound, as is currently the case in the United States. In general, the more accommodative the monetary policy stance the larger is the impact of government spending on GDP.

Similarly, the economy's response to a rise in government expenditure depends on how the additional spending is financed (see, for instance, Ludvingson (1996) or Leeper, Walker, and Yang (2010)). In general, theory predicts that, when taxes are distortionary, government spending that is deficit-financed (i.e., paid for with future taxes) will lead to larger effects on employment and output than when the spending is paid for with higher current taxes. In addition, the size of the effects will also depend on whether the increase in government spending is transitory or permanent, with more persistent increases in spending leading to larger effects on output. Quantitative macroeconomic models predict that permanent increases in infrastructure spending can have a very large impact on GDP, with a long run multiplier as large as 8 for values 
of the output elasticity of public capital at the high end of the range of empirical estimates (see, for instance, Baxter and King (1993)). ${ }^{3}$ However, these models predict much smaller short-run multipliers, even when the increase in infrastructure spending is permanent.

The remainder of the paper is organized as follows. In the next section, we discuss the main empirical findings for the effects of government investment spending on economic activity. We start with a review of the literature relating specifically to transportation infrastructure investment in the United States. We then place the evidence from that literature in the context of the broader literature on the impact of total government investment (i.e., including nontransportation). We conclude the section with a discussion of the evidence for some other industrialized countries. In Section 3, we compare the evidence relating to transportation and total government investment spending to that relating to government non-investment spending and taxes. Section 4 provides a discussion of studies that estimate separate effects of government spending in recessions versus expansions.

\section{The effects of public investment}

\subsection{Investment in transportation infrastructure}

The empirical literature on the economic effects of overall (stimulus and non-stimulus) government spending has generally concentrated on the impact of military spending, putting relatively little emphasis on public infrastructure spending. The main reason for this focus is that most macroeconomic frameworks have modeled the effects of nonproductive government expenditures - that is, expenditures that are not thought to increase the productivity of private firms - and military spending is considered a good proxy for this kind of expenditure when testing these models’ predictions empirically. Moreover, military spending is thought to be relatively independent of the business cycle in the United States. For instance, the work of Barro (1981) has been very influential in arguing that U.S. military spending associated with major

\footnotetext{
${ }^{3}$ The empirical literature on the output elasticity of public capital - i.e., the private-sector productivity gains from public capital - is quite mixed. Papers by Aschauer (1989), Morrison and Schwartz (1996), and Fernald (1999) find large productivity gains, while studies by Holtz-Eakin (1994) and Holtz-Eakin and Schwartz (1995) find no evidence of productivity gains.
} 
wars can largely be thought of as being exogenous to U.S. economic activity because their timing was unrelated to economic conditions in the United States. The emphasis on military spending thus mitigates the problem of reverse causation discussed in the introduction and offers a more convincing approach to estimating the effect of a change in government spending on economic activity.

However, in responding to weak economic conditions the government rarely relies on military spending as a form of stimulus (though some observers (e.g., Feldstein (2008)) did propose increases in military spending in response to the decline in growth in 2008). In an influential article, Blanchard and Perotti (2002) proposed a new strategy to instead identify the effect of nonmilitary spending on the economy, and this methodology has been used in most subsequent studies on the impacts of infrastructure spending. Their strategy relies partly on the fact that, because of political and bureaucratic delays, fiscal policy cannot be changed instantaneously and so, at high enough frequencies (for instance, within a quarter), fiscal policy cannot contemporaneously react to unforeseen economic developments, again mitigating problems of reverse causation.

One important study, by Pereira (2000), adopts this strategy to study the effects of different types of infrastructure spending. He considers a multiple-equation econometric system that includes private GDP, private investment, and alternative types of public investment (by federal, state, and local governments) from 1956 to 1997 using annual data. As a result, Pereira assumes that Congress cannot react within a year to changes in economic conditions. The study reports, among other statistics, the long run (cumulative) multipliers for total infrastructure spending and its breakdown into: (a) highways and streets, (b) electric and gas facilities and transit systems, (c) sewage and water supply systems, (d) public buildings (schools, hospitals, etc.), and (e) conservation and development structures (intended for water, land, and animal protection).

Pereira finds a long run multiplier of 4.5 for total public investment, while for investment in transportation infrastructure his estimate is roughly 2, the lowest estimate across the different types of infrastructure spending. Translating the results in terms of rates of return, his findings 
imply a 3.4 percent rate of return on public investment in transportation infrastructure. Unfortunately, Pereira (2000) does not report estimates of short-run multipliers. ${ }^{4}$

One concern with this study is that the timing restriction imposed on the data to capture a causal relationship between government investment and GDP may not hold for annual data. (Blanchard and Perotti (2002) use quarterly data with this form of timing restriction.) That is, it seems unrealistic to think that the U.S. Congress is unable to respond to unforeseen changes in economic activity within twelve months. For instance, President George W. Bush signed into law the Economic Stimulus Act, which provided tax rebate payments to households, in February 2008, only two months after the official start of the recession, even though the National Bureau of Economic Research (NBER) had not yet declared the start of the recession and would not do so for several more months. In addition, as the recession intensified with the failure of Lehman Brothers and the subsequent seizing-up of financial markets, Congress was able to introduce additional major legislation very quickly. On October 3, 2008, only two weeks after Lehmann Brothers declared bankruptcy, Congress passed the Troubled Asset Relief Program. While this example shows that Congress can act quickly when the economy is in a tailspin, Congress has also responded fairly rapidly during milder downturns. For instance, the Economic Growth and Tax Relief Reconciliation Act was adopted in January 2001, less than a year after the U.S. economy (officially) entered a much milder downturn. As a result, using a timing assumption that limits fiscal policy to react to economic developments within one year might be problematic and lead to biased estimates of fiscal policy’s economic effects.

Another potentially problematic aspect of the methodology is that it fails to address the fact that public infrastructure spending is likely to be anticipated long before it actually shows up in government statistics. Such anticipation can occur because infrastructure legislation is often designed to ease long-term planning necessary for infrastructure projects. For instance, federal highway legislation is typically enacted for multi-year periods and provides details about total annual dollar amounts of highway grants for each year of the legislation, as well as the

\footnotetext{
${ }^{4}$ In a follow-up paper, Pereira and Andraz (2004) use a similar methodology as in Pereira (2000), but look at the regional (instead of national) effects of highway spending using a panel data set of U.S. states. In particular, they examine whether the estimated output multiplier at the national level can be ascribed to regional spillovers across states. They find that 80 percent of the aggregate effect can be traced back to regional spillovers. Note, however, that the study does not report standard errors around the estimates and so it's impossible to assess the statistical significance of the results.
} 
mechanism (e.g., formulas and formula factors) through which the grants will be apportioned across states. With this information, states' transportation departments and the public in general can more easily forecast how much a given state is likely to receive in future highway grants. If economic agents are forward-looking enough, changes in those expectations (i.e., forecasts) can then influence current economic activity.

Even short-term fiscal stimulus legislation often can be anticipated at least one quarter in advance. Consider the example of the American Recovery and Reinvestment Act passed in February 2009. The Survey of Professional Forecasters (SPF) in 2008:Q4 and 2009:Q1 contained special survey questions about the possibility of a fiscal stimulus package. For responses received on or before Nov. 10, 2008 (the 2008:Q4 SPF), 69\% expected a stimulus package in 2009. In an important recent study, Ramey (2011a) showed that failing to capture anticipation effects can lead to misleading inference about the effects of changes in government spending. In particular, if there are anticipation effects, changes in government spending (or even authorizations of changes to future spending such as the ARRA authorization in February 2009) may occur after some or all of the economic effects that should be attributed to those changes.

Alternative approaches that do not rely on the above timing restriction have also been used in the literature to capture causal effects. In a recent paper, Leduc and Wilson (forthcoming) use the institutional design of federal highway grants distribution among states to examine the short-run and long-run effects of exogenous movements in government highway spending on states' economic activity between 1993 and 2010. One advantage of this approach is that it addresses directly the problem of anticipation effects by constructing forecasts of future highway grants and using the revisions in these forecasts as a measure of unanticipated movements in spending. It captures causal effects in part by exploiting the fact that the apportionment of highway grants to states is based on road-related formula factors measured three years prior. The reliance on road-related factors, which are only tangentially related to economic conditions, combined with the three-year measurement lag help decouple how much a state receives in federal grants from that state's current economic activity. 
Leduc and Wilson find that unanticipated changes in highway grants lead to both a positive effect on states GDP on impact ( 0 to 1 years after the shock) and 6 to 8 years out. ${ }^{5}$ Many other macroeconomic variables (employment, productivity, wages and salaries, etc.) following a similar pattern, though the initial impact is absent for employment and wages. Translating their results into multipliers, they report an average multiplier of 1.3 over an 11-year horizon. However, the multipliers at specific horizons can be much larger, from nearly 3 on impact to a peak multiplier of 6 around 6-8 years out. Using a theoretical model of regions within a monetary and fiscal union, they also show that this distinct pattern is consistent with a short-run Keynesian demand effect followed by a medium-run productivity effect that occurs once the new public capital stock is available for production.

Leduc and Wilson also report results addressing the specific question in the title of this report, namely, whether transportation spending should be used as a form of stimulus spending. Infrastructure spending, because it is perceived as being more productive (in the sense of increasing private sector productivity) than other types of spending, is often pointed to as an ideal form of countercyclical fiscal spending. However, critics argue that the long lags between increases in infrastructure funding and actual spending make such spending incapable of providing short-run benefits. Leduc and Wilson found that, on average over the 1993 - 2010 sample period, unanticipated funding increases in a given state boost GDP in the short-run but do not boost employment. In an extension, they show that the short-run GDP boost appears to be driven by funding shocks that occur during recessions, though even recession shocks do not appear to boost employment. They also found that the short-run (and long-run) GDP effects of highway funding shocks are smaller for states whose GDP is growing slower than the median state. Those results would seem to suggest that highway spending - at least the kind of highway spending typically done over the past twenty years - may not be well-suited to be an effective type of stimulus spending.

However, Leduc and Wilson also found that the highway funding shocks occurring during 2009, the year of the ARRA stimulus package as well as the trough of the Great Recession, had unusually large short-run impacts on GDP. One notable aspect of ARRA highway grants to states is that they came with a requirement to be "obligated" - that is, put to

\footnotetext{
${ }^{5}$ Throughout the text we will sometimes refer to unanticipated changes in spending as "shocks."
} 
work on projects - within one year, a far shorter implementation lag than is the case with ordinary highway grants. A possible interpretation of these results is that, on average, highway spending may not be especially effective at providing short-run stimulus, but that it can be effective during times of very high economic slack and especially when the spending can be structured so as to reduce the usual implementation lags. ${ }^{6}$

It is also important to note that Leduc and Wilson's estimates are not directly comparable to those from Pereira (2000)'s study because they do not capture any aggregate effects that are constant across states at a given point in time and that have been removed through the inclusion of time fixed effects in the regressions. For instance, Leduc and Wilson's multiplier estimates are independent of the Federal Reserve's monetary policy during the period studied or of the impact of deficit- or tax-financing of federal government spending on highway grants, and should be interpreted as local multipliers, not aggregate ones. That said, using their simulated theoretical model, Leduc and Wilson show that with current-tax-financing of federal spending and monetary policy rules consistent with observed monetary policy behavior in recent decades, the aggregate peak multiplier on infrastructure investment is roughly one-half the size of the local multiplier. This result, of course, is sensitive to the assumptions regarding deficit vs. tax financing of federal spending and monetary policy behavior. In particular, either deficit financing or more accommodative monetary policy (such as at the zero lower bound) yield a higher aggregate multiplier.

Another important study of the local effects of highway investment is that of Chandra and Thompson (2000). They propose an interesting quasi-experimental approach to identify the causal effects of public investment in interstate highways. They suggest examining the effects of new highway construction in the non-metropolitan counties that happen to lie between the cities that the new highways were intended to connect. In other words, because (it is argued) the location of interstate highways was chosen primarily to connect economically important metro areas and without regard to the economic conditions of the non-metro areas that happen to lie in between, these non-metro areas can be thought of as being more or less randomly "treated" with

\footnotetext{
${ }^{6}$ Another paper that contains results related to the short-run impacts of infrastructure investment during downturns is that of Fishback and Kachanovskaya (2010), which estimates the local (state) multiplier of federal spending during the Great Depression. They found a personal income multiplier on public works grants and relief transfers (they do not separate between the two) of 1.62, which is larger than the multiplier of 1.39 they find on total federal grants.
} 
a new highway. One can then compare the post-highway-completion economic outcomes of these treated areas to the outcomes of non-treated areas, that is, non-metro counties far away from any highway. ${ }^{7}$ Looking at county-level data between 1969 and 1993, they find that counties that receive a highway experience a rise in earnings roughly 10 years after the opening of the new highway. They also show that this increase in earnings comes partially at the cost of falling earnings in counties adjacent to counties receiving the new highways: rising activity in "highway" counties thus draws activity away from adjacent counties. Interestingly, when looking at the effects of a new highway on the regional economy (i.e., combining both highway and adjacent counties) and taking into account the typical 2-6 year period for highway construction mentioned in the introduction, Chandra and Thompson's results are quite similar to those of Leduc and Wilson (forthcoming): economic activity increases during the initial years of highway construction (that is, several years prior to a highway opening) and then again roughly 6-8 years later (that is, around 2-5 years after a highway opening). However, Chandra and Thompson do not report multiplier estimates, which make a direct comparison with the above studies more challenging.

More recently, Datta (2012) used a very similar identification strategy to assess the impact of India’s “Golden Quadrilateral” highway improvement program on businesses that happened to be situated on the highway routes connecting India's four largest cities. Datta found that subsequent to the highway improvements these businesses were able to reduce input inventories and reported decreased transportation obstacles compared with businesses not near the highways.

A number of other influential studies on the impact of transportation infrastructure have not directly focused on the stimulative effects of increases in such spending, but instead examined its effects on suburbanization (Baum-Snow (2007)) or on trade and the relative price of factors of production (Michaels (2008)). More closely related to the topic of interest here, Duranton and Turner (2011) estimate the effects of interstate highways on urban employment. In particular, they look at the effects of a city's stock of highways in 1983 on that city's employment growth over the subsequent 20 years. As in Baum-Snow (2007) and Michaels (2008), Duranton and Turner use the 1947 plan of the interstate highway system to address

\footnotetext{
${ }^{7}$ Banerjee, Duflo, and Qian (2012) propose a similar approach to study the effects of railroads in China.
} 
potential concerns of reverse causation, since cities with high expected future employment growth, as of 1983, may have received more highway construction funds to facilitate this expected growth. Empirically, it turns out that the 1947 plan (and even older railroad routes or

the routes of major explorer expeditions in the mid-1800s) predicts the stock of cities' highways in 1983 fairly accurately. Because the 1947 plan is unlikely to have been designed in response to anticipation of employment growth between 1983 and 2003, it thus provides an exogenous determinant of cities' highway stocks. They find that a city with 10 percent higher highway lanemiles, as predicted by the 1947 plan, saw about 1.5 percent faster employment growth between 1983 and 2003.

\subsection{Total government investment}

While the number of studies specifically looking at the effects of investment in transportation infrastructure on economic activity is relatively small, there is a larger literature that has examined the effects of total government investment on GDP. The results from that literature can complement those based on transportation investment spending, as such spending accounts for a significant share of total government investment. In 2006, for instance, U.S. transportation investment spending made up about one third of total public investment by all levels of government combined. In addition, the results based on total government investment provide context for assessing whether transportation investment yields larger or smaller economic effects than other types of government investment.

Using the methodology proposed by Blanchard and Perotti (2002), Perotti (2004) examines the effect of unanticipated changes in government investment at different horizons form 1960Q1 to 2001Q4. Because of its use of quarterly data, this study is less subject (though not entirely immune) to the problem of reverse causation discussed in the previous section, since it is more difficult for policymakers to respond to economic developments within a quarter than within a year. Perotti estimates a vector autoregression (VAR) model with 6 variables: government consumption, government investment, net taxes, inflation, interest rates, and GDP in which taxes and government investment have been cyclically adjusted for the automatic movements in these variables to changes in GDP (due, e.g., to so-called “automatic stabilizers”). 
He finds a short-run multiplier of roughly 1.7, but a long-run multiplier (after 5 years) of only 0.4. The low long-run multiplier is partly due to a large crowding out effect on private investment.

In a more recent paper, Afonso and Aubyn (2009) use a similar approach to examine the effect of total government investment (i.e., gross fixed capital formation at all levels of government) on private investment and GDP. Similar to Perotti (2004), they use a VAR model with five variables - private investment, public investment, real GDP, taxes, and real interest rates - and a data interval that runs from 1961 to 2004 at an annual frequency. They report a long run cumulative multiplier of 1.8, though this estimate is not significant at standard confidence levels. Although this study does not explicitly examine the short-run effects of government investment expenditures, a look at the response of GDP to an exogenous movement in government investment suggests that the short-run effect on output would also be insignificant. Contrary to Perotti (2004), the use of annual data makes this work more vulnerable to concerns about reverse causation and may partly explain the difference in results across the two studies.

Alternative empirical models have also been examined by Kamps (2005) who uses a vector error-correction model, which allows for cointegrating relationships between the variables included in the framework. Compared to the above two studies, Kamps looks at the effects of movements in government capital stocks (i.e., cumulative past investment net of depreciation) instead of current government investment between 1960 and 2001, using annual data. Again, it assumes that the public capital stock does not react to changes in economic conditions within a given year. As in Afonso and Aubyn (2009), he finds that the effects on GDP are insignificant at all horizons.

\subsection{Evidence from other countries}

The effects of investment in transportation infrastructure can also be informed from the evidence uncovered in different industrialized countries. The evidence in Japan during the 1990s is particularly interesting as it shares some broad economic similarities with the U.S. economy in the aftermath of the financial crisis. To mitigate the decline in growth, the Japanese Diet adopted 
no less than 15 spending packages between 1990 and 2000, with public works accounting for roughly 35 percent of the total size of the packages. ${ }^{8}$

In an early study of the effects of those stimulus measures, Kuttner and Posen (2002) adopt the Blanchard and Perotti (2002) methodology and estimate small VAR models with taxes, government expenditures, and GDP, where taxes and government spending have been cyclically adjusted to remove the automatic effects of changes in GDP on those variables. The measure of government spending used in this study is broad and includes current consumption and investment expenditures, net of social security and interest payments. Using this model, they examine the effects of a cumulative 1 percent increase in government spending over a 4-year horizon, assuming a zero cumulative effect on taxes. ${ }^{9}$ They find a cumulative 4-year multiplier of 2 .

Other studies of fiscal policy in foreign countries have used regional variations in infrastructure spending to assess its effect on regional economic activity. For instance, Brückner and Tuladhar (2011), look at the effects of federal government investment across Japan’s 47 prefectures on value added in those prefectures between 1990 and 2000. The panel regression is estimated with time-invariant prefecture fixed effects and year fixed effects. As in Leduc and Wilson (forthcoming) above, the effects of monetary policy or national fiscal policy are captured by the year fixed effects and therefore do not influence the estimated impact of government investment on prefectures’ GDP. Brückner and Tuladhar find a small impact multiplier of roughly 0.3 , which rises to 0.7 after one year. Decomposing the effects by types of government investment, they find that industry investment, which includes transportation spending, had an even smaller impact multiplier of about 0.2. One possibility for the low multipliers in Japan may be the very transitory nature of the expenditure packages, which according to theory, would provide less stimulus. The problem of reverse causation may also be influencing the results as it could be that government investment was directed to prefectures experiencing larger drops in growth, which would bias the estimates downward. ${ }^{10}$

\footnotetext{
${ }^{8}$ On average, the fiscal stimulus packages accounted for 2.7 percent of GDP. See Brückner and Tuladhar (2011).

${ }^{9}$ However, note that during that period increases in government spending in Japan tended to be quickly followed by a rise in taxes. So keeping taxes constant in this exercise is not innocuous.

${ }^{10}$ The paper does not attempt some instrumental variables regressions to address this concern; however it lacks strictly exogenous instruments. Rather, it uses lagged changes in government spending as an exogenous predictor of
} 
In a similar fashion, a recent paper by Leigh and Neill (2011) estimated a static, crosssection IV regression of local unemployment rates on local federally-funded infrastructure spending in Australia. Because much of that spending in Australia is determined by discretionary earmarks rather than formulas, they use political power of localities as instruments for grants received by localities. Though one might be concerned that local political power also might affect local economic conditions, invalidating the instruments, they find that local highway grants substantially reduced local unemployment rates over the three-year period between 2001 and 2004.

Using an interesting quasi-experiment, Acconcia, Corsetti, and Simonelli (2012) examine the effects of changes in public works across Italian provinces on local economic activity. They address the issue of causality by using the changes in public works spending resulting from the legally-mandated interruption of such spending upon evidence of mafia infiltration in a local city council. Such spending interruptions are argued to be unrelated to current local economic conditions. $^{11}$ They estimate an output multiplier of roughly 2.

\section{Comparison with other types of government spending}

The estimated effects of government investment in infrastructure on the economy can be compared to those of other types of government spending. In this section, we will relate the infrastructure effects discussed earlier to those from studies on the effects of military spending, government consumption, and taxes. As in the case of infrastructure spending, the estimated multipliers vary substantially according to the method of estimation, the time period studied, and the identification strategy.

As mentioned in Section 2.1, the empirical literature on the effects of fiscal policy has tended to concentrate on military spending. In an influential paper, Ramey and Shapiro (1998) propose a narrative approach to identify exogenous movements in military spending caused by military events abroad and hence likely to be exogenous to the U.S. business cycle. They identified 3 dates with "news shocks" of military buildups associated with the Korean War, the

current levels of government spending. If the government changes spending (for a prefecture) this year partly in response to expected economic conditions next year or beyond, then lagged changes will not be a valid instrument.

${ }^{11}$ A concern with this approach, however, is that it does not control for province-level fixed effects. It may well be that provinces where mafia infiltration, and corruption more generally, is prevalent suffer lower economic growth on average as a result. If this is the case, mafia infiltration is not exogenous to current economic conditions. 
Vietnam War, and the Soviet invasion of Afghanistan. In more recent work, they have augmented their shock dates to include 9/11. This methodology has been used in many other papers as well: Edelberg, Eichenbaum, and Fisher (1999), Burnside, Eichenbaum, and Rebelo (2004), Eichenbaum and Fisher (2005), and Cavallo (2005). Surveying this literature, Ramey (2011) reports a range of multiplier estimates between 0.6 and 1.2, depending on the data sample and on the particular type of multiplier (cumulative versus peak, for instance). The size of the short-run multiplier tends to be toward the low end of this range.

Section 2.1 also mentioned the work of Blanchard and Perotti (2002), which proposed a new methodology to identify exogenous movements in non-military government spending that partly relies on the implementation lags of fiscal policy. Blanchard and Perotti find that government spending has a relatively small effect on GDP, with a multiplier less than one either on impact or over the short and medium run.

In turn, the range of estimates for tax multipliers is also very wide. For instance, Romer and Romer (2010) examine the reasons behind changes in U.S. federal tax rates identifying those related to boosting long-term growth or to reducing an inherited budget deficit as exogenous to current economic conditions. Regressing real GDP growth on this measure of (arguably) exogenous tax changes, they find a large peak multiplier of 3 (meaning that a $\$ 1$ tax cut increases real GDP by \$3). However, this result has been shown to be sensitive to the methodology used. For instance, Favero and Giavazzi (forthcoming) imbed this shock measure in a dynamic, multiple-equation system and find that the peak multiplier is less than 1. Alternatively, Mountford and Uhlig (2009) use economic theory to derive sign restrictions for the theoretical responses of economic variables to tax increases. These restrictions are then imposed in dynamic, multiple-equations models (VARs) to identify exogenous movements in taxes empirically. As in Romer and Romer (2010), they find a large multiplier that peaks at 5, five years after the tax increase.

\section{Government Spending in Good Times and Bad Times}

As discussed in Parker (2011), surprisingly little of the research on the effects of government spending has differentiated between the effects of spending during recessions and 
effects during expansions, despite the obvious policy importance of knowing whether countercyclical fiscal policy is effective at smoothing out business cycle fluctuations. Fortunately, this situation appears to be changing as a number of recent papers have focused either on how the fiscal multipliers vary according to the state of the business cycle or on the size of the multiplier during specific downturns.

Several recent papers have extended the Blanchard and Perotti SVAR approach, to allow for different effects (multipliers) of government spending during recessions and expansions. Auerbach and Gorodnichenko (2012), Fazzari, et al. (2012), and Baum and Koester (2011) each follow this approach and find that the economic boost provided by government spending is large during recessions, but small or non-existent during expansions. Auerbach and Gorodnichenko (2011) also look at whether the fiscal multiplier differs in recessions versus expansions, but use a different technique for identifying exogenous shocks to government spending. They used changes in private forecasts of government spending to identify such shocks. ${ }^{12}$ In particular, they use the errors in one-yearahead forecasts of government spending to identify the part of spending that is unanticipated and then use this component as an exogenous movement in government spending. They consider an empirical model that allows for the effects of spending to vary over the business cycle and find that the GDP multiplier of government spending is significantly larger during downturns than during expansions. Depending on the type of forecasts used to control for expectations and depending on the measure of the multiplier, they report estimates of the GDP multiplier that vary between -1.3 and 1.2 for expansions and between 2.1 and 7.1 for recessions.

Several recent papers have looked at the economic effects of government spending during the most recent downturn. Wilson (2012), Feyrer and Sacerdote (2012), and Conley and Dupor (2012) each looked at the employment effects of the stimulus spending from the 2009 American Recovery and Reinvestment Act (ARRA) using state-level data on employment and stimulus received. Though their data and regression specifications differed, each attempted to isolate the causal effect of the stimulus on subsequent employment change using exogenous drivers, or "instruments," that help determine how much stimulus a given state receives while being

\footnotetext{
${ }^{12}$ They consider forecasts of government spending from the Survey of Professional Forecasters, forecasts from the staff of the Federal Reserve Board prior to FOMC meetings, and forecasts from the University of Michigan's RSQE macroeconometric model.
} 
uncorrelated with current economic conditions in the state. Wilson, for instance, exploited the fact that the cross-state distribution of most ARRA spending was determined by pre-existing formulas that rely on formula factors unrelated to current economic activity. For example, the DOT's ARRA funds were apportioned using highway-related factors that were lagged several years, as discussed earlier in relation to the work of Leduc and Wilson. Similarly, the Department of Education's ARRA grants were distributed based on a state's youth population. Both Wilson and Feyrer and Sacerdote find relatively large total and private-sector employment effects of ARRA spending, while Conley and Dupor find positive and significant total employment effects but are unable to reject a zero effect for the private sector (though their confidence intervals are fairly large).

Another paper exploiting cross-state variation in government spending is Shoag (2010). Shoag looks at data on government spending and personal income across states over the past twenty years. He first shows that states’ pension fund returns, which are unlikely to be correlated with current state economic conditions, are strong predictors of state government spending. He then uses those returns as instruments and finds that predicted government spending is strongly associated with personal income. Specifically, the results suggest a personal income multiplier of government spending of about 1.5. Moreover, he finds that the multiplier is much larger, as high as 3, during local downturns. Similarly, Holden and Sparrman (2011) used cross-country panel data to estimate the short-run effects of government spending and found them to be much larger during recessions.

Johnson, Parker, and Souleles (2006) and Parker, Souleles, Johnson, and McClelland (2011) also looked at the effects of specific countercyclical tax policies during the recessions of 2001 and 2007-2009. They use the fact that the timing of disbursement of federal tax rebates was effectively randomized to identify the causal effect on household-level consumption of a temporary decline in taxes. These studies found that the fall in taxes caused a boost in the consumption of non-durable goods and services by between a quarter and a half of the amount of the rebate, with the boost larger for households more likely to be cash-constrained. The implied “marginal propensity to consume” (MPC), or how much households consume out of a given dollar of rebate payment, is larger than standard theory would predict given the payments were only temporary and a small share of lifetime income. One possible reason for the large MPC is 
that more people were cash- and/or borrowing-constrained during these downturns than during normal times, when the MPC might be closer to theoretical predictions.

\section{Conclusion}

This report summarized the economic literature on the effects of government spending with a particular focus on transportation infrastructure investment and on the effects of government spending during times of recession - i.e., stimulus spending. As the report has made clear, there are relatively few studies directly related either to transportation investment or to stimulus spending, and the interaction between the two is sparse indeed. To our knowledge, the only paper that provides empirical estimates specifically of the short-run economic impact of transportation spending during downturns is Leduc and Wilson (2012). They find that, on average between 1993 and 2010, highway spending provided a short-run boost to GDP but not to employment. Yet, the impact of such spending was found to be large during periods of pronounced economic slack, such as the most recent recession.

More generally, studies of transportation infrastructure spending have focused on the longer-run effects, tending to find substantial impacts on real GDP, employment, population flows, and interregional trade. In contrast, studies of overall government spending, even on investment, typically have found small or zero long-run effects, though some find sizable shortrun impacts. The literature has only begun in recent years to study the differential effect of government spending in recessions versus expansions. Auerbach and Gorodnichenko (2011), in particular, have found that government spending on average has much larger effects on macroeconomic outcomes during recessions. Studies of economic stimulus transfer payments (e.g., tax rebates), on the other hand, have found rather modest effects.

Returning to the central question of the paper, should transportation spending be included in a stimulus program? It is clear that the economics literature to date does not provide a definitive answer. Our assessment of the evidence so far is that transportation spending is associated with larger economic benefits than other types of government spending which generally do not increase the productivity of private sector production. In addition, both theory and empirical evidence strongly suggest that government spending during recessions has more 
beneficial short-run effects than does spending during expansion. Yet, these findings do not necessarily imply that government transportation spending is an effective stimulus measure. Whether it is likely depends on the nature of the spending, whether it can be implemented quickly, the condition of the existing transportation infrastructure, and the nature of the recession. It is hoped that further research in this area will shed a brighter light on these issues.

\section{References}

Acconcia, Antonio, Giancarlo Corsetti, and Saverio Simonelli (2011). "Mafia and Public Spending: Evidence on the Fiscal Multiplier from a Quasi-experiment,” Mimeo, University of Naples Federico II.

Afonso and Aubyn (2009). "Macroeconomic rates of return of public and private investment: crowding-in and crowding-out effects," Manchester School 77 (S1): 21-39.

Aschauer, David (1989). “Is Public Expenditure Productive?” Journal of Monetary Economics, 23, pp. 177-200.

Auerbach, Alan J., and Yuriy Gorodnichenko (2011). "Fiscal Multipliers in Recession and Expansion,” NBER Working Paper \#17447.

Auerbach, Alan J., and Yuriy Gorodnichenko (2012). "Measuring the Output Responses to Fiscal Policy,” American Economic Journal: Economic Policy.

Baum, Anja, and Garrett Koester (2011), "The impact of fiscal policy on economic activity over the business cycle - evidence from a threshold VAR analysis,” Deutsche Bank Discussion Paper Series 2011:03.

Baum-Snow, Nathaniel (2007). “Did Highways Cause Suburbanization?” Quarterly Journal of Economics.

Banerjee, Abhijit, Esther Duflo, and Nancy Qian (2012). "On the Road: Access to Transportation Infrastructure and Economic Growth in China,” NBER Working Paper \#17897.

Barro, Robert J, 1981. "Output Effects of Government Purchases," Journal of Political Economy 89(6): 1086-1121.

Baxter, Marianne, and Robert G. King (1993). “Fiscal Policy in General Equilibrium,” American Economic Review, Vol. 83, pp. 315-334.

Blanchard, O., and R. Perotti (2002). "An Empirical Characterization of the Dynamic Effects of Changes in Government Spending,” Quarterly Journal of Economics, 117(4), pp. 13291368.

Brückner, Marius, and Tuladhar (2011). "The Effectiveness of Government Expenditures During Crisis: Evidence from Regional Government Spending in Japan 1990-2000,” Mimeo, International Monetary Fund. 
Burnside, Craig, Martin Eichenbaum, and Jonas D. M. Fisher. 2004. "Fiscal Shocks and Their Consequences.” Journal of Economic Theory 115(1): 89-117.

Cavallo, Michele (2005). "Government Employment Expenditure and the Effects of Fiscal Policy Shocks,” Federal Reserve Bank of San Francisco Working Paper 2005-16.

Chandra, A. and E. Thompson, (2000). "Does Public Infrastructure Affect Economic Activity? Evidence from the Rural Interstate Highway System,” Regional Science and Urban Economics 30, pp. 457-490.

Christiano, Lawrence J., Eichenbaum, Martin, and Sergio Rebelo (2010). "When is the Government Spending Multiplier Large?” Federal Reserve Bank of Atlanta CQER Working Paper 10-01.

Congressional Budget Office (2012). "Estimated Impact of the American Recovery and Reinvestment Act on Employment and Economic Output from July 2011 Through September 2011.”

Duranton, Gilles, and Matthew A. Turner (2011). "The Fundamental Law of Road Congestion: Evidence from U.S. Cities,” American Economic Review 101, 2616-2652.

Edelberg, Wendy, Martin Eichenbaum, and Jonas D. M. Fisher (1999). "Understanding the Effects of a Shock to Government Purchases," Review of Economic Dynamics 2, 166206.

Eichenbaum, Martin, and Jonas D. M. Fisher (2005), "Fiscal Policy in the Aftermath of 9/11," Journal of Money, Credit, and Banking 37, 1-22.

Favero, Carlo, and Francesco Giavazzi (2010). "Reconciling VAR-based and Narrative Measures of the Tax Multiplier," American Economic Journal: Economic Policy, forthcoming.

Fazzari, Steven M., James Morley, and Irina Panovska (2012). “State-Dependent Effects of Fiscal Policy,” Mimeo, Australian School of Business.

Feldstein, M. (2008). “Defense Spending Would Be Great Stimulus,” Wall Street Journal.

Fernald, John (1999). "Roads to Prosperity? Assessing the Link between Public Capital and Productivity,” American Economic Review, June 1999, 619-638.

Fishback, Price V., and Valentina Kachanovskaya. 2010. “In Search of the Multiplier for Federal Spending in the States During the New Deal,” NBER Working Paper No. 16561.

Government Accountability Office (2002). "Highway Infrastructure: Preliminary Information on the Timely Completion of Highway Construction Projects.” Testimony before the Committee on Environment and Public Works, U.S. Senate.

Holden, Steinar, and Victoria Sparrman (2011). "Do government purchases affect unemployment?” Mimeo, University of Oslo.

Holtz-Eakin, Douglas, (1994). “Public-sector Capital and the Productivity Puzzle,” Review of Economic and Statistics 76(1), 12-21.

Holtz-Eakin, Douglas, and Amy E. Schwartz (1995). "Spatial Productivity Spillovers from Public Infrastructure: Evidence from State Highways,” International Tax and Public Finance, 2: 459-468.Johnson, David S., Jonathan A. Parker, and Nicholas S. Souleles 
(2006). "Household Expenditure and the Income Tax Rebates of 2001.” American Economic Review 96(5): 1589-1610.

Kamps, Christophe (2005). "The Dynamic Effects of Public Capital: VAR Evidence for 22 OECD Countries," International Tax and Public Finance 12(4): 533-558.

Kuttner, Kenneth N. \& Posen, Adam S. (2002). "Fiscal Policy Effectiveness in Japan," Journal of the Japanese and International Economies 16(4), 536-558.

Leduc, Sylvain, and Daniel J. Wilson (2012). "Roads to Prosperity or Bridges to Nowhere? Theory and Evidence on the Impact of Public Infrastructure Investment.” NBER Macroeconomics Annual 2012, forthcoming. Editors Daron Acemoglu, Jonathan Parker, and Michael Woodford.

Leeper, Eric M., Todd B. Walker, Shu Chun Susan Yang (2010), “Government Investment and Fiscal Stimulus,” Journal of Monetary Economics 57, 1000-1012.

Ludvigson, Sydney (1996). "The Macroeconomic effects of government debt in a stochastic growth model,” Journal of Monetary Economics 38 (1), 25-45.

Leigh, Andrew, and Christine Neil (2011), "Can national infrastructure spending reduce local unemployment? Evidence from an Australian roads program,” Economics Letters 113, pp. 150-153.

Michaels, Guy (2008). "The Effect of Trade on the Demand for Skill: Evidence from the Interstate Highway System,” Review of Economics and Statistics 90(4): 683-701.

Morrison, Catherine J., and Amy Ellen Schwartz (1996). "State Infrastructure and Productive Performance,” American Economic Review, 86(5), pp. 1095-1111.

Mountford, A., and H. Uhlig (2009). "What are the Effects of Fiscal Policy Shocks?” Journal of Applied Econometrics, 24(6), pp. 960-992.

Parker, Jonathan A., Nicholas S. Souleles, David S. Johnson, and Robert McClelland (2011). "Consumer Spending and the Economic Stimulus Payments of 2008." National Bureau of Economic Research Working Paper 16684.

Pereira, Alfredo R. (2000). “Is All Public Capital Created Equal?” Review of Economics and Statistics 82(3), 513-518.

Pereira, Alfredo and Jorge Andraz (2004). "Public highway spending and state spillovers in the USA," Applied Economics Letters 11(12), 785-788.

Perotti, R. (2004). "Public Investment: Another (different) Look,” mimeo, Università Bocconi.

Ramey, V.A. (2011). "Identifying Government Spending Shocks: It’s all in the Timing," Quarterly Journal of Economics 126(1), 1-50.

Shapiro, Matthew D., and Joel Slemrod (2003). “Consumer Response to Tax Rebates,” American Economic Review 93(1), 381-396.Summers, Lawrence H., 2008. "Summary of Testimony to House Budget Committee.”Wilson, Daniel J. (2012a). “Government Spending: An Economic Boost?” Federal Reserve Bank of San Francisco Economic Letter, February 6, 2012. 
Wilson, Daniel J. (2012b). "Fiscal Spending Jobs Multipliers: Evidence from the 2009 American Recovery and Reinvestment Act,” American Economic Journal: Economic Policy, forthcoming. 
Table 1.

\section{Recent Estimates of the Multiplier on Public Transportation Spending}

\begin{tabular}{|c|c|c|c|}
\hline Study & Short Term Effect & Long Term Effect & Methodology/Description \\
\hline Pereira (2000) & n.a. & 1.97 & $\begin{array}{l}\text { VAR - annual } \\
\text { Highway and streets } \\
\text { 1956-1997 }\end{array}$ \\
\hline Leduc and Wilson (2012) & 2.7 & 6.2 & $\begin{array}{l}\text { Direct projections on state panel } \\
\text { data - annual } \\
\text { Federal highway grants to states } \\
\text { 1993-2010 }\end{array}$ \\
\hline $\begin{array}{l}\text { Chandra and } \\
\text { Thompson (2000) }\end{array}$ & $\begin{array}{l}\text { Regional earnings } \\
\text { rise during early } \\
\text { construction years }\end{array}$ & $\begin{array}{l}\text { Regional earnings rise } \\
6 \text {-8 years after highway } \\
\text { opens }\end{array}$ & $\begin{array}{l}\text { Univariate regressions on county } \\
\text { panel data - annual } \\
\text { Highways } \\
1969-1993\end{array}$ \\
\hline Perotti (2004) & 1.47 & 0.37 & $\begin{array}{l}\text { VAR - quarterly } \\
\text { Total government investment } \\
\text { 1960Q1-2001Q4 }\end{array}$ \\
\hline Kamps (2005) & $\begin{array}{c}\text { Not } \\
\text { significant }\end{array}$ & $\begin{array}{c}\text { Not } \\
\text { significant }\end{array}$ & $\begin{array}{l}\text { Vector error correction - annual } \\
\text { Public capital stocks } \\
\text { 1960-2001 }\end{array}$ \\
\hline Afonso and Aubyn (2009) & $\begin{array}{c}\text { Not } \\
\text { significant }\end{array}$ & $\begin{array}{c}\text { Not } \\
\text { significant }\end{array}$ & $\begin{array}{l}\text { VAR - annual } \\
\text { Total government investment } \\
\text { 1961-2004 }\end{array}$ \\
\hline
\end{tabular}


Table 2

The Implementation Lags of Highway Spending

\begin{tabular}{lcc}
\hline & Obligations & Outlays \\
\hline FHWA Grants & $\mathbf{0 . 7 0 0}$ & $\mathbf{0 . 1 2 2}$ \\
& $(0.106)$ & $(0.064)$ \\
FHWA grants, lagged 1 year & $\mathbf{0 . 3 4 5}$ & $\mathbf{0 . 5 2 6}$ \\
& $(0.133)$ & $(0.081)$ \\
FHWA grants, lagged 2 years & -0.037 & $\mathbf{0 . 1 0 8}$ \\
& $(0.101)$ & $(0.062)$ \\
FHWA grants, lagged 3 years & -0.020 & $\mathbf{0 . 0 4 4}$ \\
& $(0.038)$ & $(0.023)$ \\
FHWA grants, lagged 4 years & -0.016 & $\mathbf{0 . 0 5 8}$ \\
& $(0.036)$ & $(0.022)$ \\
FHWA grants, lagged 5 years & - & $\mathbf{0 . 0 5 3}$ \\
& & $(0.016)$ \\
FHWA grants, lagged 6 years & - & $\mathbf{0 . 0 6 3}$ \\
& & $(0.015)$ \\
FHWA grants, lagged 7 years & - & 0.021 \\
& & $(0.015)$ \\
Year fixed effects & Yes & Yes \\
State fixed effects & Yes & \\
Cumulative effect & $\mathbf{0 . 9 7 3}$ & $\mathbf{0 . 9 9 6}$ \\
& $(0.064)$ & $(0.042)$ \\
& & \\
\hline
\end{tabular}

Source: Leduc and Wilson (2012).

Notes: This tables shows the coeffients obtained from an OLS regression of state Federal-Aid Highway project obligations ( $2^{\text {nd }}$ column) or outlays $\left(3^{\text {rd }}\right.$ column) on the current value and seven lags of Federal Aid Highway Administration (FHWA) grants using state panel data from 1993 2008. The regression controls for state and year fixed effects. 